\title{
DNMT3A in Leukemia
}

\author{
Lorenzo Brunetti, ${ }^{1,2,3,6}$ Michael C. Gundry, ${ }^{1,2,4,6}$ and Margaret A. Goodell1,2,3,5 \\ ${ }^{1}$ Stem Cells and Regenerative Medicine Center, Baylor College of Medicine, Houston, Texas 77030 \\ ${ }^{2}$ Center for Cell and Gene Therapy, Baylor College of Medicine, Houston, Texas 77030 \\ ${ }^{3}$ CREO, University of Perugia, 06123 Perugia, Italy \\ ${ }^{4}$ Department of Molecular \& Human Genetics, Baylor College of Medicine, Houston, Texas 77030 \\ ${ }^{5}$ Texas Children's Hospital, and Houston Methodist Hospital, Houston, Texas 77030 \\ Correspondence: goodell@bcm.edu
}

DNA methylation is an epigenetic process involved in development, aging, and cancer. Although the advent of new molecular techniques has enhanced our knowledge of how DNA methylation alters chromatin and subsequently affects gene expression, a direct link between epigenetic marks and tumorigenesis has not been established. DNMT3A is a de novo DNA methyltransferase that has recently gained relevance because of its frequent mutation in a large variety of immature and mature hematologic neoplasms. DNMT3A mutations are early events during cancer development and seem to confer poor prognosis to acute myeloid leukemia (AML) patients making this gene an attractive target for new therapies. Here, we discuss the biology of DNMT3A and its role in controlling hematopoietic stem cell fate decisions. In addition, we review how mutant DNMT3A may contribute to leukemogenesis and the clinical relevance of DNMT3A mutations in hematologic cancers.

$D^{n}$ NA methylation is an epigenetic modification involved in key cellular processes such as transcriptional repression, genomic imprinting, and the suppression of repetitive elements. The first suggestion of a link between DNA methylation and cancer was the observation that human cancers tend to display global hypomethylation compared with normal controls (Feinberg and Vogelstein 1983). Subsequently, the field switched attention to focally hypermethylated regions with the hypothesis that epigenetic silencing of tumor suppressor genes through promoter hypermethylation would drive gene silencing, obviating the need for genetic inactivation of these pathways (Jones and Laird 1999). Investigators then began looking for possible genes/pathways responsible for the observed methylation changes.

The deposition and maintenance of DNA methyl marks is orchestrated by DNA methyltransferases. In mammals, three genes encoding proteins with DNA methyltransferase activity have been identified: $D N M T 1, D N M T 3 A$, and DNMT3B (Okano et al. 1998). DNMT3A and DNMT3B proteins are responsible for establishing the patterns of DNA methylation early in embryogenesis through de novo methylation of unmethylated CpG sites (Okano et al. 1999), and DNMT1 maintains such patterns throughout cell division by targeting hemimethylated

${ }^{6}$ These authors contributed equally to this work.

Editors: Scott A. Armstrong, Steven Henikoff, and Christopher R. Vakoc

Additional Perspectives on Chromatin Deregulation in Cancer available at www.perspectivesinmedicine.org

Copyright (C) 2017 Cold Spring Harbor Laboratory Press; all rights reserved; doi: 10.1101/cshperspect.a030320

Cite this article as Cold Spring Harb Perspect Med 2017;7:a030320 
L. Brunetti et al.

DNA and copying the methyl mark onto the nascent DNA strand. All three proteins are essential for mammalian development (Okano et al. 1999).

Since the discovery of altered DNA methylation patterns in human cancers, an abundance of data has been collected on the expression levels of the DNMT genes in tumors, with overexpression of DNMT1 the most frequently observed change (Issa et al. 1993; Robertson et al. 1999). In addition, overexpression of the de novo methyltransferases (DNMT3A/DNMT3B) has been broadly reported in cancers (Mizuno et al. 2001; Girault et al. 2003; Oh et al. 2007; Rahman et al. 2010), supporting an oncogenic role for the DNMT family proteins. The success of DNA hypomethylating agents, including 5-azacytidine and decitabine, in the treatment of a multiple hematologic malignancies further supported this hypothesis (Santini 2012).

It, therefore, came as a surprise when genomic studies uncovered loss-of-function mutations in the DNMT family across multiple cancers (Gao et al. 2011; Yang et al. 2015). Most strikingly, DNMT3A mutations are frequently detected in a variety of adult hematologic malignancies, often occurring as early events during leukemogenesis (Roller et al. 2013; Shlush et al. 2014; Yang et al. 2015). Since this discovery, the development of mouse models and biochemical studies on DNMT3A have improved our understanding of the function of DNMT3A and its role in normal and malignant hematopoiesis. However, significant questions remain unanswered regarding both molecular mechanisms and clinical prognostic and therapeutic value. Herein, we review the known biology of DNMT3A and discuss recent clinical studies with therapeutic implications for DNMT3A mutations in cancer.

\section{DNMT3A STRUCTURE}

DNMT3A is a $130-\mathrm{kDa}$ protein that is highly conserved in vertebrates, with $98 \%$ homology between humans and mice (Okano et al. 1998; Xie et al. 1999). The gene is encoded by 23 exons on human chromosome 2 p23 and is expressed in two major forms: a long isoform,
DNMT3A1, and a short isoform, DNMT3A2 (Fig. 1), which has been the subject of most studies because of its predominant expression in mouse embryonic stem (mES) cells (Chen et al. 2002). DNTM3A2 has been shown to interact with DNMT3L, a catalytically inactive member of the methyltransferase family whose expression is restricted to germ cells and early embryogenesis (Hata et al. 2002). Disruption of this interaction through loss of either protein leads to defects in imprinting and spermatogenesis (Kaneda et al. 2004; Nimura et al. 2006).

DNMT3A contains three well-studied domains. The Pro-Trp-Trp-Pro (PWWP) domain synergistically binds DNA and specific histone marks in gene bodies (see more below) (Wang et al. 2014). The ATRX-DNMT3-DNMT3L (ADD) domain binds $\mathrm{H} 3$ tail peptides (Otani et al. 2009). The $S$-adenosyl methionine (SAM)-dependent methyltransferase C5-type domain encodes the highly conserved methyltransferase (MTase) domain (Fig. 1), which recognizes and binds DNA, and after binding the cofactor SAM, attaches a methyl group to the $\mathrm{C} 5$ position of cytosine. The long isoform also contains 219 extra amino acids at the amino terminus, which have been shown to enhance the DNA-binding affinity and methylation activity of the protein in vitro (Suetake et al. 2011). De novo germline mutations in each of the three major domains occur in the recently described Tatton-BrownRahman syndrome (or DNMT3A overgrowth syndrome), which is characterized by tall stature, a distinctive facial appearance, and intellectual disability (Tatton-Brown et al. 2014).

In the nucleus, DNMT3A can exist in oligomeric form as dimers, tetramers, and larger structures through two distinct binding interfaces in the MTase domain. The oligomers are composed of homodimeric DNMT3A molecules or heterodimeric DNMT3A-DNMT3L molecules; however, the presence of a single binding interface in DNMT3L prevents further oligomerization past a 3L-3A-3A-3L tetramer state (Jurkowska et al. 2011). The structure of the tetramer allows for coordinated methylation of two independent CpG sites at an average distance of $\sim 9$ bp (Zhang et al. 2009). Importantly, both the DNA and SAM binding affinity of 
DNMT3A in Leukemia
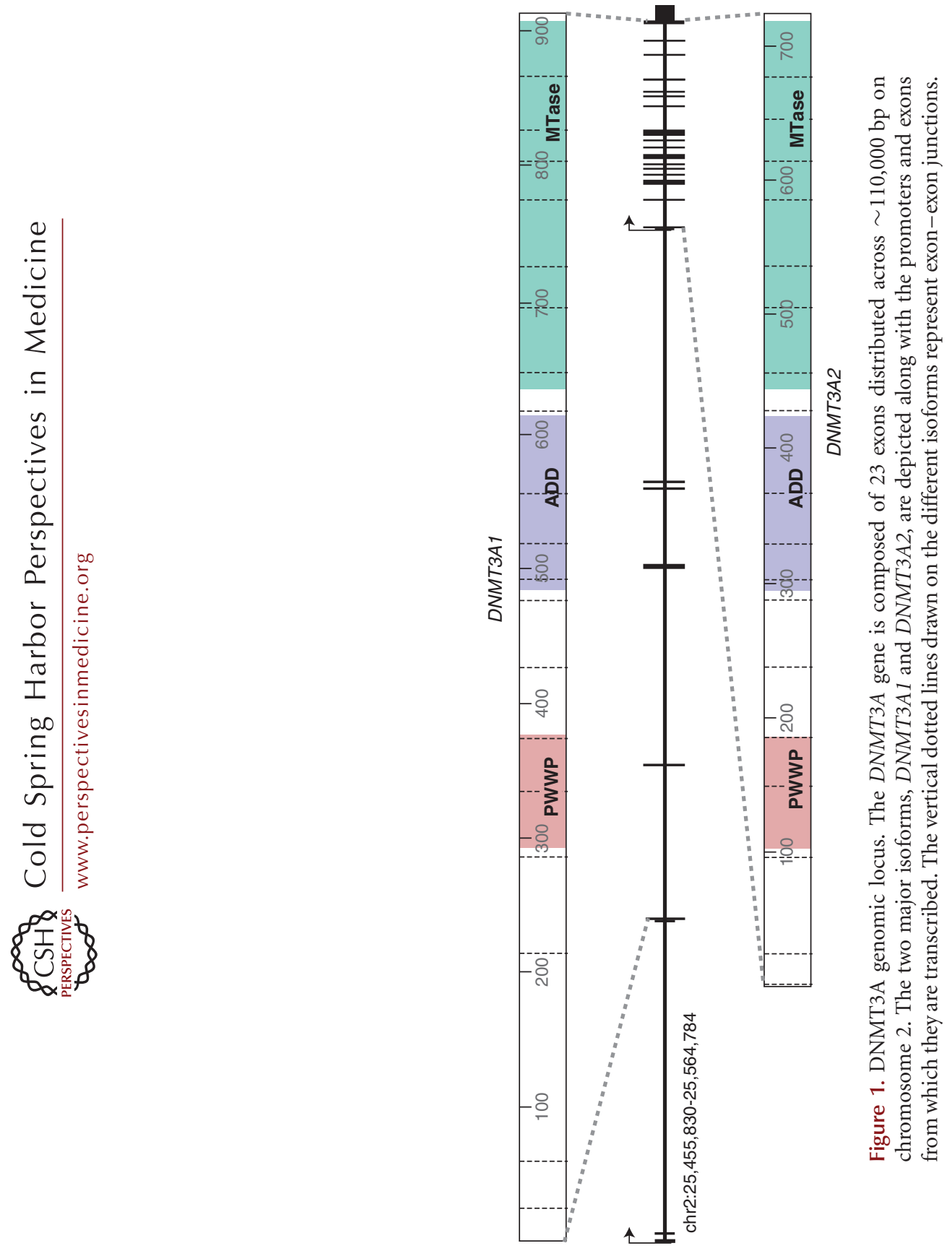
L. Brunetti et al.

DNMT3A, as well as the processivity of the enzyme, are tied to the oligomeric state of DNMT3A (Holz-Schietinger et al. 2011). In addition to programmed changes in oligomerization, such as those driven by developmental changes in DNMT3L expression and differential DNMT3A/3B isoform usage, a number of pathologic alterations including mutations at DNMT3A binding interfaces (Holz-Schietinger et al. 2012) have been shown to affect oligomerization and alter cell behavior. So far, oligomerization in adult somatic tissues, which lack DNMT3L, has not been assessed. It is possible that complex oligomers composed of different isoforms of DNMT3A and DNMT3B exist and that the dosages of these complexes affect regional de novo methylation. Further work is needed to better understand the regulation and importance of oligomerization on cellular phenotypes including cancer.

\section{DNMT3A AND DNA METHYLATION}

The distribution of $\mathrm{mCpGs}$ in the mammalian genome is nonrandom and the mechanism responsible for targeting DNMT3A and DNMT3B to specific genomic regions remains largely unknown. However, functional characterization of DNMT3A domains and studies on DNMT3A binding patterns and de novo methylation activity in embryonic stem cells (ESCs) have shed some light on the intrinsic and extrinsic factors controlling regional specificity.

Each of the three major domains in DNMT3A has been shown to associate with specific epigenetic marks. Crystal structure analysis recently showed an elegant autoinhibitory mechanism for DNMT3A, wherein the ADD domain physically blocks the MTase domain (Guo et al. 2015). When histone H3 with an unmodified lysine 4 tail is encountered (H3K4me0), the ADD-MTase interaction is disrupted, resulting in movement of the ADD domain enabling enzymatic activity. However, in the presence of amino-terminal H3 tail modifications, especially $\mathrm{H} 3$ lysine 4 trimethylation (H3K4me3), release from autoinhibition is significantly less efficient, providing a mechanism to ensure that actively expressed genes (marked by $\mathrm{H} 3 \mathrm{~K} 4 \mathrm{me} 3)$ are not subject to DNA methylation (Ooi et al. 2007; Otani et al. 2009; Zhang et al. 2010). Mutations in the ADD domain are found in some hematologic cancers. Although most cancer-associated DNMT3A mutations are presumed to represent a loss of function, it is conceivable that $\mathrm{ADD}$ domain mutations could result in loss of autoinhibition, leading to a gain of function and aberrant hypermethylation of actively expressed genes marked by histone $\mathrm{H} 3 \mathrm{~K} 4 \mathrm{me} 3$, ultimately leading to their suppression; this scenario remains to be tested.

Similarly, the PWWP domain binds DNA and trimethylated histone $\mathrm{H} 3$ lysine 36 (H3K36me3) (Dhayalan et al. 2010). $\mathrm{H} 3 \mathrm{~K} 36 \mathrm{me} 3$ marks active chromatin and is highly enriched in gene bodies and repetitive elements, including pericentromeric DNA (Chantalat et al. 2011). Indeed, DNMT3A colocalizes with pericentromic heterochromatic foci, and disruption of the PWWP domain in ES cells leads to a diffuse nuclear patterning of DNMT3A and a loss of methylation activity at major satellite repeats in pericentric heterochromatin (Chen et al. 2004). During gametogenesis and early embryogenesis, protection of the germline through suppression of repetitive elements is critical; this suppression may represent a major function of the PWWP domain during embryonic development. Furthermore, both the H3K36 methyltransferase SETD2 and the PWWP domain of DNMT3B have been shown to be required for targeting de novo methylation to transcribed genes (Baubec et al. 2015); thus, it is possible that the PWWP domain of DNMT3A acts in a similar manner.

Finally, the MTase domain of DNMT3A has been shown to preferentially bind unmethylated DNA (Yokochi and Robertson 2002). In vitro experiments have shown that some CpG flanking bases, specifically AT-rich sequences, can enhance methylation activity by several orders of magnitude (Lin et al. 2002), consistent with genome-wide data on enriched sequence motifs at methylated CpGs (Handa and Jeltsch 2005). As discussed previously, the MTase domain also cooperatively oligomerizes on DNA, forming nucleoprotein filaments that enhance the activity of the enzyme and confer a processive- 
like property to the protein (Emperle et al. 2014). The majority of somatic mutations in DNMT3A are heterozygous and act to disrupt this oligomerization, suggesting a key role for oligomerization in the normal function or stability of the protein.

Other chromatin-modifying enzymes have also been shown to associate with DNMT3A and may impact DNA methylation patterns. The majority of these binding partners associate either directly or indirectly with the ADD domain, including heterochromatin protein 1 (HP1), histone deacetylase 1 (HDAC1), UHRF1, and the histone lysine $N$-methyltransferases (EZH2, SUV39H1/2, SETDB1, and G9a) (Ayyanathan et al. 2003). The interplay between histone modifications and DNA methylation is complex, and the order of acquisition of histone marks and DNA methylation differs according to the specific histone mark and chromatin enzyme involved (Cedar and Bergman 2009). More data is needed on the complex relationships between histone marks and DNA methylation to trace the origin of epigenetic patterning during embryogenesis. Additionally, the relationship between these epigenetic marks in adult somatic tissues has not been studied and may be key to understanding the role of DNMT3A in cancer.

\section{DNMT3A IN HEMATOPOIESIS}

Although the majority of studies on DNMT3A have been performed in ESCs and germ cells, recent work indicates that DNMT3A may also regulate somatic stem cell differentiation (Challen et al. 2012; Hu et al. 2012; Wu et al. 2012; Dhawan et al. 2015). In the mouse hematopoietic system, deletion of Dnmt3a leads to a preference for self-renewal over differentiation and gradual expansion of the long-term hematopoietic stem cell (LT-HSC) compartment on serial transplantation (Fig. 2). A similar alteration in stem-cell fate is observed on loss of DNMT3A in neural stem cells (Hu et al. 2012) and on loss of DNMT3A/3B in mouse and human ES cells (Chen et al. 2003; Challen et al. 2012; Liao et al. 2015). Deletion of Dnmt3b does not appear to have a major effect on the LT-HSC compartment, which is not surprising as the predominant DNMT3B isoform expressed in the hematopoietic system is enzymatically inactive (Challen et al. 2014). However, codeletion of Dnmt3a/3b enhanced LT-HSC expansion and virtually blocked differentiation, signifying residual DNMT3B activity.

Dnmt3a-null HSCs are phenotypically indistinguishable from wild-type cells, with similar levels of proliferation and apoptosis and an identical cell surface marker profile. Dnmt3anull HSCs retain the ability to differentiate into all hematopoietic lineages, albeit with a lower differentiation quotient or reduced level of output per LT-HSC (Fig. 2). From a molecular standpoint, Dnmt3a-null HSCs display significant genome-wide hypomethylation with focal areas of hypermethylation that can be attributed to residual DNMT3B activity. Differentially methylated regions (DMRs) identified in Dnmt3a-null HSCs are distributed across all genomic features, but are significantly enriched at the edges of large hypomethylated regions known as methylation canyons (Jeong et al. 2014). These features were recently identified in multiple cell types (Xie et al. 2013), and often occur near developmental regulatory genes such as homeobox-containing genes. Analysis of gene expression changes after loss of DNMT3A revealed that many canyon-associated genes involved in HSC self-renewal are overexpressed in Dnmt3a-null HSCs and remain inappropriately turned on in differentiated progeny cells (Challen et al. 2012; Jeong et al. 2014). However, no clear relationship between canyon hypomethylation, altered gene expression, and phenotype has been established.

The expansion of Dnmt3a-null cells observed on competitive transplantation represents a potential mechanism for early leukemic transformation. In this model, cells that spontaneously acquire a mutation in DNMT3A would be more likely to self-renew than differentiate, and would therefore be protected from stem-cell exhaustion. Under conditions of stress, in which a larger fraction of the HSC pool is forced to cycle, selection and subsequent expansion of the DNMT3A mutant HSC pool could be even more pronounced. Indeed, trans- 
L. Brunetti et al.
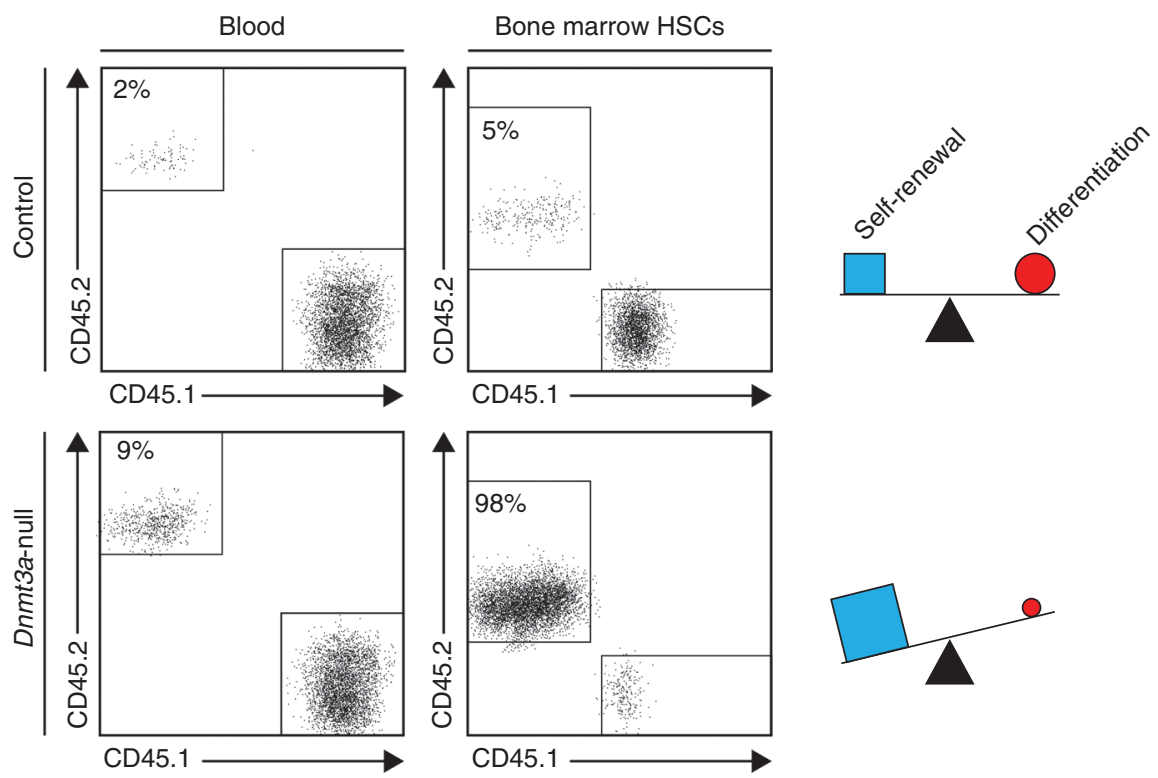

Figure 2. DNMT3A controls hematopoietic stem cell fate. In mice, serial competitive transplantation of wildtype (WT) hematopoietic stem cells (HSCs) (CD45.2) eventually leads to less efficient engraftment. The contribution of engrafted HSCs to hematopoiesis is proportional to their level of engraftment in the bone marrow (top). In contrast, Dnmt3a-null HSCs do not exhaust and instead begin to outcompete CD45.1 WT cells, resulting in an expanded contribution to the HSC compartment. The contribution of these Dnmt3a-null HSCs to blood production is minimal, reflecting an imbalance between self-renewal and differentiation driven by loss of DNMT3A (bottom).

planted Dnmt3a-null HSCs led to development of an array of myeloid and lymphoid neoplasms that recapitulate the full spectrum of human malignancies harboring DNMT3A mutations (Celik et al. 2015; Mayle et al. 2015).

\section{DNMT3A MUTATIONS AND CANCER}

Since the first description of DNMT3A mutations in acute myeloid leukemia (AML) (Ley et al. 2010), multiple exome and targeted resequencing studies have identified DNMT3A mutations in AML (Shlush et al. 2014; Klco et al. 2015; Ivey et al. 2016) as well as in a variety of other adult myeloid and lymphoid neoplasms (Roller et al. 2013). Interestingly, DNMT3A mutations are very rare in pediatric blood cancers, with the few identified mutations found in adolescents (Ho et al. 2011; Thol et al. 2011b; Shiba et al. 2012).

The majority of DNMT3A mutations found in hematopoietic disorders occur within the methyltransferase domain (MTD), with a significant enrichment for mutations at codon R882 (Fig. 3) (Cancer Genome Atlas Research 2013; Roller et al. 2013). However, non-R882 missense and truncating mutations are found in each of the major domains (Cancer Genome Atlas Research 2013; Roller et al. 2013). In AML and other myeloid neoplasms, R882 mutations are usually heterozygous (Ley et al. 2010; Cancer Genome Atlas Research 2013; Gaidzik et al. 2013; Gale et al. 2015). However, in T-cell acute lymphoblastic leukemia (T-ALL), a high frequency of non-R882 biallelic mutations has been reported (Grossmann et al. 2013; Roller et al. 2013), suggesting different selective pressures on DNMT3A mutations in myeloid and lymphoid disorders. Data from Dnmt3a/Flt3ITD double-mutant mice are consistent with an influence of DNMT3A dosage. Dnmt3a $a^{-1-}$ cells can generate both myeloid and lymphoid malignancies (Yang et al. 2016), whereas Dnmt $3 a^{+/-}$cells are more likely to develop 


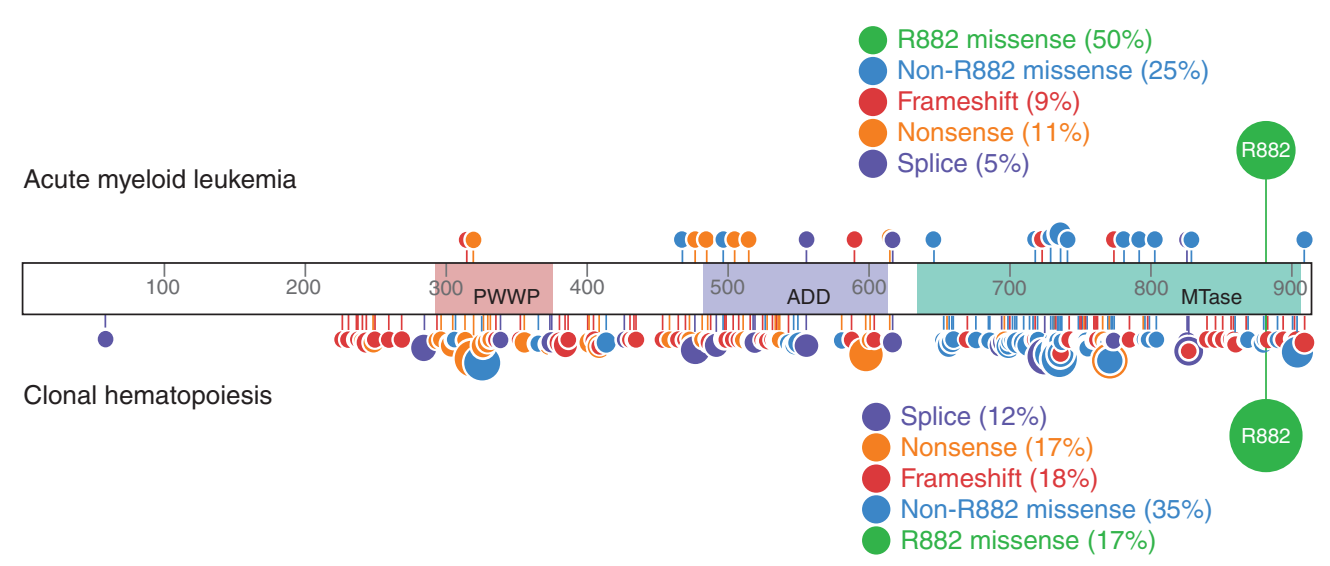

Figure 3. DNMT3A mutations in acute myeloid leukemia (AML) and clonal hematopoiesis. The spectrum of DNMT3A mutations in AML (TCGA data) and clonal hematopoiesis (Jaiswal et al. 2014) are depicted on a figure of the long isoform. AML TCGA data include 57 DNMT3A mutations from 51 individuals (cohort of 200 patients), whereas clonal hematopoiesis data include 403 DNMT3A mutations from 398 individuals (cohort of 17,182 healthy patients). Each lollipop represents a nonsynonymous mutation, with the size of the lollipop correlating to the mutation count (within the respective groups) and the color indicating the type of mutation.

myeloid cancers (Meyer et al. 2016; Yang et al. 2016). Taken together, these data strongly indicate that DNMT3A is a haploinsufficient tumor suppressor gene in myeloid leukemias, when cooperating mutations are present.

In AML, $\sim 65 \%$ of DNMT3A mutations are heterozygous missense mutations affecting codon R882 (Ley et al. 2010; Gaidzik et al. 2013; Gale et al. 2015). R882H mutation (or mouse $\mathrm{R} 878 \mathrm{H}$ mutation) has been shown to exert a dominant-negative effect over the wildtype protein (Holz-Schietinger et al. 2012; Kim et al. 2013; Russler-Germain et al. 2014). The mutant protein can dimerize with WT DNMT3A, but tetramers, which comprise a substantially more active form of the protein, are not able to form (Holz-Schietinger et al. 2012; Russler-Germain et al. 2014). The resulting low levels of DNMT3A homotetramers result in a significant reduction of methytransferase activity, providing an explanation for the genome-wide hypomethylation observed in patients with R882 mutations (Cancer Genome Atlas Research 2013; Qu et al. 2014; Meyer et al. 2016; Yang et al. 2016). In addition, the R882 mutant may acquire other deleterious interactions. Recent data suggest that it may interact with the Polycomb repressive complex 1
(PRC1), unlike WT DNMT3A, resulting in down-regulation of genes involved in promoting hematopoietic differentiation such as PU.1 and Cebpa (Koya et al. 2016).

In contrast to R882 mutations, there is still a complete lack of data related to the biological impact of non-R882 missense mutations. It is possible that mutations in different DNMT3A domains lead to different unique neomorphic functions that result in specific underlying mechanisms of pathogenesis. Characterizing the epigenetic landscapes and phenotypic effects of non-R882 missense mutations in more detail will be vital to our understanding of DNMT3A-mutated cancer biology.

\section{DNMT3A MUTATIONS IN AML}

DNMT3A mutations are detectable in $\sim 20 \%$ of patients with de novo AML, as well as in secondary AML (Table 1) evolving from previous myelodysplastic syndromes or myeloproliferative neoplasms (sAML) (Ley et al. 2010; Thol et al. 2011a; Fried et al. 2012; Gaidzik et al. 2013; Roller et al. 2013). Some clinical and pathologic features characterize $D N M T 3 A^{\text {mut }}$ AML patients at diagnosis. Compared with wild-type DNMT3A $\left(D N M T 3 A^{\mathrm{wt}}\right)$ patients, they tend to 
L. Brunetti et al.

Table 1. Prevalence of DNMT3A mutations in hematologic malignancies

\begin{tabular}{|c|c|c|c|}
\hline Disease & Characteristics & Frequency (\%) & References \\
\hline \multirow[t]{6}{*}{ Adult AML } & De novo AML & $62 / 281(22.1)$ & Ley et al. 2010 \\
\hline & De novo CN-AML & $36 / 123(29.3)$ & Renneville et al. 2012 \\
\hline & Intermediate risk AML & $272 / 914(29.8)$ & Gale et al. 2015 \\
\hline & CN-AML & $142 / 415(34.2)$ & Marcucci et al. 2012 \\
\hline & $\begin{array}{l}\text { 89.5\% de novo AML, } 10.5 \% \\
\text { s-AML and t-AML }\end{array}$ & $370 / 1770(20.9)$ & Gaidzik et al. 2013 \\
\hline & t-AML and s-AML & $\begin{array}{l}\text { t-AML 10/61 (16.4); s-AML } \\
\quad 13 / 37 \text { (35.1) }\end{array}$ & Fried et al. 2012 \\
\hline Pediatric AML & De novo AML & $2 / 206(1)$ & Liang et al. 2013 \\
\hline \multirow[t]{2}{*}{ Adult T-ALL } & T-ALL & $\begin{array}{l}\text { Entire cohort 16/83 (19.3); } \\
\quad \text { early T-ALL 10/38 (26.3) }\end{array}$ & Grossmann et al. 2013 \\
\hline & ETP ALL & $11 / 68(16.2)$ & Neumann et al. 2013 \\
\hline MPAL & Adult T/myeloid MPAL & $10 / 18(55.6)$ & Wolach and Stone 2015 \\
\hline MDS & De novo MDS & $127 / 944(13.5)$ & Haferlach et al. 2014 \\
\hline MPN & All MPNs & $10 / 155(6.5)$ & Stegelmann et al. 2011 \\
\hline \multirow[t]{3}{*}{ MDS/MPN } & $\begin{array}{l}52 \text { CMML, } 20 \text { s-AML } \\
\text { evolved from CMML }\end{array}$ & $\begin{array}{l}\text { CMML 2/52 (3.8); s-AML } \\
\text { 6/20 (30) }\end{array}$ & Jankowska et al. 2011 \\
\hline & 65 CMML-1, 38 CMML-2 & $\begin{array}{l}\text { CMML-1 2/65 (3.1); } \\
\text { CMML-2 5/38 (13.2) }\end{array}$ & Roller et al. 2013 \\
\hline & JMML & $3 / 100(3)$ & Stieglitz et al. 2015 \\
\hline \multirow[t]{3}{*}{ T-cell lymphomas } & T-cell lymphomas & $11 / 96(11.4)$ & Couronné et al. 2012 \\
\hline & AITL and PTCL-NOS & $21 / 79(26.6)$ & Sakata-Yanagimoto et al. 2014 \\
\hline & CTCL & $17 / 40(42.5)$ & Choi et al. 2015 \\
\hline
\end{tabular}

The large range of frequencies reported for AML depends on the subset of patients considered and whether the entire DNMT3A or only hotspots were sequenced.

AML, acute myeloid leukemia; CN-AML, caryotype normal-AML; t-AML, therapy-related AML; s-AML, secondary AML; T-ALL, T-cell acute lymphoblastic leukemia; ETP ALL, early T-cell precursor ALL; MPAL, mixed phenotype acute leukemia; MDS, myelodysplastic syndromes; MPN, myeloproliferative neoplasms; MDS/MPN, myelodysplastic syndrome/myeloproliferative neoplasms; CMML, chronic myelomonocytic leukemia; JMML, juvenile myelomonocytic leukemia; AITL, angioimmunoblastic lymphoma; PTCL-NOS, peripheral T-cell lymphomas not otherwise specified; CTCL, cutaneous T-cell lymphoma.

be older, have higher white blood cell counts, and be frequently diagnosed with cytogenetically normal AML (CN-AML) with myelomonocytic or monocytic (French-American-British M4 and M5) blast morphology (Thol et al. 2011a; Marcucci et al. 2012; Gaidzik et al. 2013; Gale et al. 2015).

DNMT3A ${ }^{\text {mut }}$ AMLs frequently harbor NPM1 $\left(N P M 1^{\mathrm{c}+}\right)$ and FLT3 mutations, with $60 \%-80 \%$ of $D N M T 3 A^{\text {mut }}$ cases having $N P M 1^{\mathrm{c}+}$ and $\sim 30 \%$ displaying both NPM1 and FLT3 mutations (Cancer Genome Atlas Research 2013; Gaidzik et al. 2013; Gale et al. 2015). Although there is evidence that $\mathrm{Npm}^{\mathrm{c}+} /$ Flt3-ITD mice (Mupo et al. 2013) and Dnmt3a $a^{\text {mut }} /$ Flt3-ITD mice (Meyer et al. 2016) develop leukemia with $100 \%$ penetrance, no data have been published on Dnmt3amut $N p m 1^{\mathrm{c}+}$ mice. It therefore remains unclear whether any of these mutations plays a central role in determining such specific clinical phenotype.

\section{Prognostic Impact of DNMT3A Mutations in AML}

Although a large number of studies reported that $D N M T 3 A^{\text {mut }}$ patients fare worse compared with $D N M T 3 A^{\text {wt }}$ patients (Ley et al. 2010; Shen et al. 2011; Thol et al. 2011a; Hou et al. 2012; Marcucci et al. 2012; Renneville et al. 2012; Ribeiro et al. 2012; Tie et al. 2014; Gale et al. 2015), the impact of DNMT3A mutations in clinical decision-making is still a matter of debate (Patel 
et al. 2012; Gaidzik et al. 2013). There is a lack of evidence that the increased risk of relapse is sufficient to indicate more aggressive strategies such as bone marrow transplantation during first complete remission for these patients. Interestingly, two groups reported that highdose anthracyclines might overcome the negative impact of DNMT3A mutations (Patel et al. 2012; Sehgal et al. 2015), but larger prospective trials are needed to confirm this finding. Along with their classic topoisomerase II inhibitory properties, anthracyclines can cause nucleosome eviction from open chromatin, especially when delivered at high doses (Pang et al. 2013). Some data suggest that hypomethylated regions in DNMT3A ${ }^{\text {mut }}$ AMLs have a more open chromatin (Spencer et al. 2014), and it is possible that these regions are targets for nucleosome eviction induced by high-dose anthracycline.

Whether different types of mutations (e.g., missense vs. nonsense) in different amino acids (e.g., R882 vs. non-R882) have specific clinical consequences is unknown. The largest study reported worse outcomes for patients harboring R882 mutations, but not for patients with nonR882 mutations. Gale et al. (2015) investigated the impact of DNMT3A mutations in younger patients according to NPM1 mutational status. R882 mutated patients had worse overall survival, in both $N P M 1^{\mathrm{c}+}$ and $N P M 1^{\mathrm{wt}}$ subgroups, whereas the impact of non-R882 missense mutations was evident only in the NPM1 ${ }^{\mathrm{c}+} \mathrm{pa}-$ tients, suggesting a less pronounced clinical impact for the non-R882 missense mutations. Although limited by small sample size, a subanalysis revealed that patients with DNMT3A truncating mutations had the same prognosis as DNMT3A $A^{\mathrm{wt}}$ patients. Ahn et al. reported different outcomes for patients with R882 and nonR882 mutations treated with allogeneic bone marrow transplantation. R882 mutations conferred significant adverse prognostic impact, especially when associated with FLT3-ITD, whereas patients harboring non-R882 mutations had a similar prognosis to DNMT3A wild-type patients (Gaidzik et al. 2013; Ahn et al. 2016).

Although no definitive conclusion can be drawn, merging clinical and biological data, it seems likely that R882 mutations confer a neg- ative prognosis to $D N M T 3 A^{\text {mut }}$ patients. On the other hand, non-R882 mutations are extremely heterogeneous, encompassing a variety of mutations, and therefore understanding the impact of such mutations may be difficult. Until results from larger prospective trials become available, published data suggest that patients with DNMT3A ${ }^{\text {mut }}$ AML should be stratified according to more validated risk parameters such as age, karyotype, the persistence of residual disease after treatment (i.e., minimal residual disease; MRD), and other molecular abnormalities (e.g., NPM1 ${ }^{\mathrm{c}+}$, FLT3-ITD).

\section{DNMT3A Mutations, Minimal Residual Disease, and Relapse}

DNMT3A ${ }^{\text {mut }}$ cells are frequently detectable in patients with AML with long-lasting complete remission, raising the question of whether DNMT3A should be used to monitor MRD. Pløen et al. initially reported residual R882 DNMT3A mutations in a significant fraction of cells (mutant allele frequencies between $<1 \%$ and 50\%) in samples from 14 AML patients in complete remission. Five out of 14 patients did not relapse after a median follow-up of 53 months (Pløen et al. 2014). Recently, more studies have reported no clear association between the persistence of DNMT3A mutations in complete remission and worse clinical outcomes (Jeziskova et al. 2015; Ivey et al. 2016). The presence of DNMT3A ${ }^{\text {mut }}$ cells in patients with no evidence of residual leukemia is consistent with DNMT3A mutations being preleukemic events (Corces-Zimmerman et al. 2014; Shlush et al. 2014). The detection of DNMT3A mutations after successful treatment likely reflects the persistence of preleukemic clones instead of true leukemic cells, arguing against using DNMT3A as a marker for monitoring MRD.

The prevalence of residual DNMT3A mutations after treatment makes it reasonable to consider the hypothesis of AML relapse being, at least in some cases, the result of newly acquired mutations arising in a preleukemic DNMT3Amutated clone. New prospective trials with large cohorts combined with genome-wide sequencing studies of samples acquired over time (e.g., 
L. Brunetti et al.

diagnosis, remission, and relapse) will help to answer this question over the next few years.

\section{DNMT3A MUTATIONS IN} MYELODYSPLASTIC SYNDROMES (MDSs)

As in AML, DNMT3A mutations are early events in MDSs (Walter et al. 2011; Papaemmanuil et al. 2013); however, their prevalence is significantly lower than in AML (Table 1) and their prognostic value unclear. Although some studies suggest reduced overall survival and higher probability of evolution to AML for DNMT3A ${ }^{\text {mut }}$ MDS patients (Thol et al. 2011c; Walter et al. 2011), others have shown no prognostic significance (Bejar et al. 2012; Haferlach et al. 2014).

MDS patients are often treated with hypomethylating agents such as 5-azacytidine or decitabine (Santini 2012), which are thought to inhibit DNMT1 and restore normal methylation levels at promoter regions of tumor suppressor genes (Paul et al. 2010). One study, although limited by small numbers, suggested that DNMT3A mutations are predictive of better response to hypomethylating agents (Traina et al. 2014), but the biological explanation for this behavior is unknown. Data from Dnmt3a-null HSCs and DNMT3A ${ }^{\text {mut }}$ AML patients (Yan et al. 2011; Challen et al. 2012; Qu et al. 2014) revealed that, along with global DNA hypomethylation, some regions of the genome instead gain methylation. It may be that hypomethylating agents are acting at these sites to restore normal methylation levels. Additionally, in the context of lower DNA methylation levels, 5-azacytidine and decitabine may further reduce global DNA methylation leading to a synthetically lethal phenotype and targeted cell death. More data are needed to assess the real clinical impact of DNMT3A mutations in MDS and the implications for therapeutic approaches.

DNMT3A MUTATIONS IN MYELOPROLIFERATIVE NEOPLASMS AND MYELODYSPLASTIC/ MYELOPROLIFERATIVE NEOPLASMS

Myoproliferative neoplasms (MPNs) and myelodysplastic/myeloproliferative neoplasms
(MDS/MPNs) are chronic myeloid neoplasms classically characterized by the expansion of mature myeloid cells in the bone marrow and extramedullary sites (e.g., spleen), with or without dysplastic features. DNMT3A mutations are less frequent genetic events in MPNs and MDS/ MPNs than in AML and MDSs (Table 1). JAK2 is the most frequently mutated gene in MPNs and JAK2-V617F (JAK2 ${ }^{\mathrm{V} 617 \mathrm{~F}}$ ) accounts for $>95 \%$ of mutations of this gene (Kiladjian 2012). When co-occurring with DNMT3A mutations, the order of acquisition of DNMT3A and JAK2 mutations may be relevant in defining different MPN disease phenotypes (Nangalia et al. 2015).

DNMT3A mutations are infrequent, but recurrent in MDS/MPNs. Indeed, they can be found in $\sim 2 \%$ of chronic myelomonocytic leukemia (CMML) (Jankowska et al. 2011) and 3\% of juvenile myelomonocytic leukemia (Table 1) (Stieglitz et al. 2015). Jankowska et al. reported that $25 \%$ of patients with sAML arising from previous CMML harbored DNMT3A mutations, possibly suggesting a higher probability of evolution to AML for CMML patients with DNTM3A mutations; however, this study investigated a small cohort (Jankowska et al. 2011) and larger studies are needed. As described for AML, DNMT3A ${ }^{\text {mut }}$ CMML is reported to display significantly reduced DNA methylation, mainly at intergenic and intronic regions (Meldi et al. 2015) and low-DNA methylation levels are also reported in a Dnmt3a-null MDS/ MPN mouse model (Guryanova et al. 2015). However, whether this methylation pattern impacts the disease phenotype and eventually the prognosis of MDS/MPN patients is still unknown, and more studies are required to answer these important questions.

\section{DNMT3A MUTATIONS IN LYMPHOID MALIGNANCIES}

As reported for myeloid neoplasms, DNMT3A mutations in lymphoid malignancies are recurrent (Table 1) and thought to be early events (see below). In T-ALL, the prevalence of biallelic hits is noticeably higher than in myeloid cancers (Grossmann et al. 2013; Roller et al. 2013), sup- 
porting the role of DNMT3A as a tumor suppressor in this context.

Adult early T-cell precursor ALL (ETPALL), a subset of T-ALL thought to arise from early thymocyte precursors that retain myeloid differentiating potential (Zhang et al. 2012), is particularly enriched for mutations in DNMT3A (Neumann et al. 2013). This finding creates a link between early immature T-ALL and myeloid malignancies, suggesting that some myeloid and lymphoid leukemias may arise from a shared $D N M T 3 A^{\text {mut }}$ precursor that maintains both myeloid and lymphoid potential. More studies are needed to enhance our understanding of the mechanisms that drive neoplastic differentiation toward the myeloid or lymphoid lineages.

Although DNMT3A $A^{\text {mut }}$ T-ALL patients globally seem to fare worse compared with DNMT3A ${ }^{\mathrm{wt}}$ leukemias, it should be noted that this difference might reflect the early-T phenotype, which has been linked to a more aggressive disease evolution, and not the DNMT3A mutational status itself (Grossmann et al. 2013; Roller et al. 2013; Van Vlierberghe et al. 2013). However, the limited data available so far suggest an independent impact of DNMT3A mutations and further studies will verify its value for risk stratification.

DNMT3A is also recurrently mutated in peripheral T-cell lymphomas (Table 1) (Couronné et al. 2012; Sakata-Yanagimoto et al. 2014; Choi et al. 2015). As in myeloid neoplasms, DNMT3A $A^{\text {mut }}$ tumor cells arise in an early progenitor that retains mutilineage potential, with the mutation detectable in both the neoplastic T-cells and normal B-cells of these lymphoma patients (Couronné et al. 2012). Strikingly, $\sim 70 \%$ of DNMT3A ${ }^{\text {mut }}$ cases also harbor TET2 mutations (Couronné et al. 2012) and mouse models of Dnmt3a mutation and Tet2 knockout develop both AML and T-cell malignancies (Scourzic et al. 2016; Zhang et al. 2016). The interaction between $D N M T 3 A^{\mathrm{R} 882 \mathrm{H}}$ (thought to decrease global DNA methylation levels) and loss of TET2 (thought to increase global DNA methylation levels) generated a complex methylation landscape with increased DNA methylation and reduced expression of several tumor suppressors and hypomethylation and overexpression of T-cell key genes such as Notch1 (Scourzic et al. 2016; Zhang et al. 2016). T-cell malignancies are still challenging to treat, thus a deeper understanding of these mechanisms is needed for the development of new therapeutic strategies.

\section{DNMT3A MUTATIONS LINK AGE-RELATED CLONAL HEMATOPOIESIS, PRELEUKEMIC CLONES, AND AML}

High-throughput sequencing studies showed that some somatic mutations in known cancer driver genes could be present in the blood of elderly individuals before any hematopoietic neoplasm appears (Busque et al. 2012; Wong et al. 2015). These data imply the possibility that predisposing mutations can be acquired early on during cancer development and that only a fraction of subjects with such mutations would eventually develop cancer. Recently, four independent groups reported the presence of subclonal somatic mutations in the peripheral blood of individuals with no history of hematologic diseases (Genovese et al. 2014; Jaiswal et al. 2014; Xie et al. 2014; McKerrell et al. 2015). The prevalence of this phenomenon increased with age, with $>10 \%$ of subjects over 70 having at least one detectable somatic mutation. DNMT3A was by far the most frequently mutated gene in clonal hematopoiesis (Genovese et al. 2014; Jaiswal et al. 2014; Xie et al. 2014).

Individuals with clonal hematopoiesis have approximately a 10-fold higher risk of developing hematologic cancers compared with individuals without clonal hematopoiesis (Genovese et al. 2014; Jaiswal et al. 2014). Although the association with an increased risk of blood cancers may seem intuitive, strikingly clonal hematopoiesis is also found to significantly increase the risk of all-cause and cardiovascularrelated mortality and these risks are higher in subjects with higher levels of clonality (Genovese et al. 2014; Jaiswal et al. 2014). Because several cells types that play key roles in the pathogenesis of cardiovascular diseases (e.g., macrophages) arise from hematopoietic progenitors, mutant cells could display altered functions that 
L. Brunetti et al.

lead to an increased risk of coronary heart disease and ischemic stroke. Yet, it is unclear whether different somatic mutations associated with clonal hematopoiesis have different impacts on the risk of developing different diseases.

Organismal aging is known to be associated with decreased HSPCs fitness and alterations in the bone marrow microenvironment. Somatic mutations in some leukemia driver genes may allow for clonal expansion through increasing cellular fitness and promoting HSC self-renewal independent of age-related environmental changes. Alternatively, positive selection for cells with mutations in some genes may require the altered fitness landscape of aged bone marrow (McKerrell and Vassiliou 2015). DNMT3A mutations may confer a selective advantage to the cells in which they arise through both mechanisms. Although it has been shown that Dnmt3a-null HSCs have an enhanced serial engraftment capacity (Challen et al. 2012), less is known about the interaction of DNMT3A mutant cells and the surrounding environment. The aging microenvironment may select for the expansion of DNMT3A mutant cells at the expense of wild-type cells. Indeed, it has recently been reported that patients with autoimmune bone marrow failures such as aplastic anemia frequently harbor DNMT3A mutated clones (Yoshizato et al. 2015). These clones may expand as a result of stem cell exhaustion of wild-type HSCs forced to enter the cell cycle because of the profound cytopenia induced by marrow failure.

Whichever the mechanism leading to clonal expansion of hematopoietic progenitors, it seems likely that clonal hematopoiesis represents a primitive stage in the development of hematologic neoplasms. The vast majority of the genes reported as mutated in individuals with clonal hematopoiesis are well-known drivers of leukemia or MDS and many of them have been found in preleukemic clones in patients with AML (Corces-Zimmerman et al. 2014; Shlush et al. 2014). Preleukemic HSPCs may represent progenitors of patients with a history of clonal hematopoiesis that, after acquiring secondary genetic events, developed AML. It remains to be established why only a small frac- tion of patients with clonal hematopoiesis develop hematologic cancers and what are the molecular and biological mechanisms that regulate the transition from clonal hematopoiesis to preleukemia and eventually to cancer. Addressing these issues would significantly enhance the development of new, targeted therapies to treat patients with MDS and leukemias.

\section{THERAPEUTIC PERSPECTIVES AND FUTURE DIRECTIONS}

DNMT3A mutations are one of the earliest genetic events during hematopoietic cancer development, making this gene an attractive target for new therapeutic approaches. Moreover, the negative overall worse prognosis for DNMT3A ${ }^{\text {mut }}$ patients necessitates more efficient therapies. However, we still need to better understand how DNA methylation is regulated and how it impacts gene expression and phenotype. Although loss of DNMT3A may promote expression of self-renewal genes (Challen et al. 2012), whether these are viable candidates for therapeutic targets is unknown. The development of genome-wide CRISPR-Cas9 screens may facilitate the rapid detection of synthetically lethal phenotypes in normal and malignant hematopoietic cells (Koike-Yusa et al. 2014; Shi et al. 2015). The application of these screens to mouse and cell-based models will allow us to unravel the possible downstream effects of DNMT3A ${ }^{\text {mut }}$ HSCs and discover potential targets for DNMT3A mutated cancers.

Beside high-dose anthracycline, there is a lack of data related to new strategies for DNMT3A ${ }^{\text {mut }}$ patients with AML or other hematologic cancers. DNMT3A mutants may play a role in up-regulating $H O X$ genes in AML. Novel H3-methyltransferase inhibitors such as DOT1L inhibitors (McLean et al. 2014), MLLmenin interaction inhibitors (Borkin et al. 2015), and MLL inhibitors (Cao et al. 2014) showed efficient knockdown of HOX cluster genes and leukemic cell death, both in vitro and in vivo. Although these compounds were mainly tested in the context of $M L L$-rearranged leukemia, a wider spectrum of leukemias, including $D N M T 3 A^{\text {mut }}$ AML, may be sensitive 
to this treatment. The bone marrow niche plays a relevant role in both hematopoietic and leukemic stem cell survival and function and it has been already proposed as a possible target for novel therapies (Krause et al. 2013). Both mouse and human data support the idea of a DNMT3A ${ }^{\text {mut }}$ HSC having a competitive advantage over the wild-type counterpart (Fig. 2), but no study assessed the interplay between DNMT3A ${ }^{\text {mut }}$ cells and the microenvironment so far. Specific connections between DNMT3A ${ }^{\text {mut }}$ HSCs and the niche are likely to occur and they may promote expansion of DNMT3A ${ }^{\text {mut }}$ clones, supporting age-related clonal hematopoiesis and leukemogenesis. A better understanding of these interactions will provide new insight for the development of novel therapeutic approaches.

\section{CONCLUDING REMARKS}

DNMT3A has recently been identified as one of the most commonly mutated genes in adult hematologic malignancies. The development of Dnmt $3 a^{\text {mut }}$ mouse models has increased our understanding of how DNMT3A controls differentiation and self-renewal in the hematopoietic system and confirmed its role as a driver of leukemogenesis. The observation that Dnmt3anull HSCs have a selective advantage over wildtype cells is consistent with the high prevalence of DNMT3A mutations in patients with clonal hematopoiesis, as well as with the detection of mutant DNMT3A in preleukemic clones, and with the persistence of DNMT3A-mutant cells in patients with AML in complete remission. However, whether these mutant cells are a long-term risk factor for leukemia relapse and need to be cleared with more aggressive therapies, such as allogeneic bone marrow transplantation, remains unclear. To develop new therapeutic strategies for the treatment of patients with DNMT3A mutations, it is crucial to better characterize the role of mutant DNMT3A in initiating and maintaining tumorigenesis.

\section{ACKNOWLEDGMENTS}

We thank C. Gillespie for critical reading of the manuscript. L.B. is funded by the University of
Perugia Ph.D. program. M.C.G. is supported by Baylor Research Advocates for Student Scientists and Cancer Prevention and Research Institute of Texas Training Grant RP160283. We also acknowledge support from the $\mathrm{Na}$ tional Institutes of Health (NIH) (DK092883, CA183252), Cancer Prevention \& Research Institute of Texas (CPRIT) (RP140001), the Samuel Waxman Cancer Research Foundation, and the Edward P. Evans Foundation.

\section{REFERENCES}

Ahn JSS, Kim HJJ, Kim YKK, Lee SSS, Jung SHH, Yang DHH, Lee JJJ, Kim NY, Choi SH, Jung CW, et al. 2016. DNMT3A R882 mutation with FLT3-ITD positivity is an extremely poor prognostic factor in patients with normal-karyotype acute myeloid leukemia after allogeneic hematopoietic cell transplantation. Biol Blood Marrow Transplant 22: 61-70.

Ayyanathan K, Lechner MS, Bell P, Maul GG, Schultz DC, Yamada Y, Tanaka K, Torigoe K, Rauscher FJ III. 2003. Regulated recruitment of HP1 to a euchromatic gene induces mitotically heritable, epigenetic gene silencing: A mammalian cell culture model of gene variegation. Genes Dev 17: 1855-1869.

Baubec T, Colombo DF, Wirbelauer C, Schmidt J, Burger L, Krebs AR, Akalin A, Schubeler D. 2015. Genomic profiling of DNA methyltransferases reveals a role for DNMT3B in genic methylation. Nature 520: 243-247.

Bejar R, Stevenson KE, Caughey BA, Abdel-Wahab O, Steensma DP, Galili N, Raza A, Kantarjian H, Levine RL, Neuberg D, et al. 2012. Validation of a prognostic model and the impact of mutations in patients with lower-risk myelodysplastic syndromes. J Clin Oncol 30: 3376-3382.

Borkin D, He S, Miao H, Kempinska K, Pollock J, Chase J, Purohit T, Malik B, Zhao T, Wang J, et al. 2015. Pharmacologic inhibition of the Menin-MLL interaction blocks progression of MLL leukemia in vivo. Cancer Cell 27: 589-602.

Busque L, Patel JP, Figueroa ME, Vasanthakumar A, Provost S, Hamilou Z, Mollica L, Li J, Viale A, Heguy A, et al. 2012. Recurrent somatic TET2 mutations in normal elderly individuals with clonal hematopoiesis. Nat Genet 44: $1179-1181$.

Cancer Genome Atlas Research N. 2013. Genomic and epigenomic landscapes of adult de novo acute myeloid leukemia. N Engl J Med 368: 2059-2074.

Cao F, Townsend EC, Karatas H, Xu J, Li L, Lee S, Liu L, Chen Y, Ouillette P, Zhu J, et al. 2014. Targeting MLL1 H3K4 methyltransferase activity in mixed-lineage leukemia Mol Cell 53: 247-261.

Cedar H, Bergman Y. 2009. Linking DNA methylation and histone modification: Patterns and paradigms. Nat Rev Genet 10: 295-304.

Celik H, Mallaney C, Kothari A, Ostrander EL, Eultgen E, Martens A, Miller CA, Hundal J, Klco JM, Challen GA. 
L. Brunetti et al.

2015. Enforced differentiation of Dnmt3a-null bone marrow leads to failure with c-Kit mutations driving leukemic transformation. Blood 125: 619-628.

Challen GA, Sun D, Jeong M, Luo M, Jelinek J, Berg JS, Bock C, Vasanthakumar A, Gu H, Xi Y, et al. 2012. Dnmt3a is essential for hematopoietic stem cell differentiation. Nat Genet 44: 23-31.

Challen GA, Sun D, Mayle A, Jeong M, Luo M, Rodriguez B, Mallaney C, Celik H, Yang L, Xia Z, et al. 2014. Dnmt3a and Dnmt3b have overlapping and distinct functions in hematopoietic stem cells. Cell Stem Cell 15: 350-364.

Chantalat S, Depaux A, Hery P, Barral S, Thuret JY, Dimitrov S, Gerard M. 2011. Histone H3 trimethylation at lysine 36 is associated with constitutive and facultative heterochromatin. Genome Res 21: 1426-1437.

Chen T, Ueda Y, Xie S, Li E. 2002. A novel Dnmt3a isoform produced from an alternative promoter localizes to euchromatin and its expression correlates with active de novo methylation. J Biol Chem 277: 38746-38754.

Chen T, Ueda Y, Dodge JE, Wang Z, Li E. 2003. Establishment and maintenance of genomic methylation patterns in mouse embryonic stem cells by Dnmt3a and Dnmt3b. Mol Cell Biol 23: 5594-5605.

Chen T, Tsujimoto N, Li E. 2004. The PWWP domain of Dnmt3a and Dnmt3b is required for directing DNA methylation to the major satellite repeats at pericentric heterochromatin. Mol Cell Biol 24: 9048-9058.

Choi J, Goh G, Walradt T, Hong BS, Bunick CG, Chen K, Bjornson RD, Maman Y, Wang T, Tordoff J, et al. 2015. Genomic landscape of cutaneous T cell lymphoma. Nat Genet 47: 1011-1019.

Corces-Zimmerman RM, Hong WJ, Weissman IL, Medeiros BC, Majeti R. 2014. Preleukemic mutations in human acute myeloid leukemia affect epigenetic regulators and persist in remission. Proc Natl Acad Sci 111: 2548-2553.

Couronné L, Bastard C, Bernard OA. 2012. TET2 and DNMT3A mutations in human T-cell lymphoma. $N$ Engl J Med 366: 95-96.

Dhawan S, Tschen SI, Zeng C, Guo T, Hebrok M, Matveyenko A, Bhushan A. 2015. DNA methylation directs functional maturation of pancreatic beta cells. J Clin Invest 125: 2851-2860.

Dhayalan A, Rajavelu A, Rathert P, Tamas R, Jurkowska RZ, Ragozin S, Jeltsch A. 2010. The Dnmt3a PWWP domain reads histone 3 lysine 36 trimethylation and guides DNA methylation. J Biol Chem 285: 26114-26120.

Emperle M, Rajavelu A, Reinhardt R, Jurkowska RZ, Jeltsch A. 2014. Cooperative DNA binding and protein/DNA fiber formation increases the activity of the Dnmt3a DNA methyltransferase. J Biol Chem 289: 29602-29613.

Feinberg AP, Vogelstein B. 1983. Hypomethylation distinguishes genes of some human cancers from their normal counterparts. Nature 301: 89-92.

Fried I, Bodner C, Pichler MM, Lind K, Beham-Schmid C, Quehenberger F, Sperr WR, Linkesch W, Sill H, Wölfler A. 2012. Frequency, onset and clinical impact of somatic DNMT3A mutations in therapy-related and secondary acute myeloid leukemia. Haematologica 97: 246-250.

Gaidzik VI, Schlenk RF, Paschka P, Stolzle A, Spath D, Kuendgen A, von Lilienfeld-Toal M, Brugger W, Derigs HG, Kremers S, et al. 2013. Clinical impact of DNMT3A mutations in younger adult patients with acute myeloid leukemia: Results of the AML Study Group (AMLSG). Blood 121: 4769-4777.

Gale RE, Lamb K, Allen C, El-Sharkawi D, Stowe C, Jenkinson S, Tinsley S, Dickson G, Burnett AK, Hills RK, et al. 2015. Simpson's Paradox and the impact of different DNMT3A mutations on outcome in younger adults with acute myeloid leukemia. J Clin Oncol 33: 20722083.

Gao Q, Steine EJ, Barrasa MI, Hockemeyer D, Pawlak M, Fu D, Reddy S, Bell GW, Jaenisch R. 2011. Deletion of the de novo DNA methyltransferase Dnmt3a promotes lung tumor progression. Proc Natl Acad Sci 108: 18061-18066.

Genovese G, Kähler AK, Handsaker RE, Lindberg J, Rose SA, Bakhoum SF, Chambert K, Mick E, Neale BM, Fromer M, et al. 2014. Clonal hematopoiesis and blood-cancer risk inferred from blood DNA sequence. N Engl J Med 371: 2477-2487.

Girault I, Tozlu S, Lidereau R, Bieche I. 2003. Expression analysis of DNA methyltransferases $1,3 \mathrm{~A}$, and $3 \mathrm{~B}$ in sporadic breast carcinomas. Clin Cancer Res 9: 44154422.

Grossmann V, Haferlach C, Weissmann S, Roller A, Schindela S, Poetzinger F, Stadler K, Bellos F, Kern W, Haferlach T, et al. 2013. The molecular profile of adult T-cell acute lymphoblastic leukemia: Mutations in RUNX1 and DNMT3A are associated with poor prognosis in T-ALL. Genes Chromosomes Cancer 52: 410-422.

Guo X, Wang L, Li J, Ding Z, Xiao J, Yin X, He S, Shi P, Dong L, Li G, et al. 2015. Structural insight into autoinhibition and histone H3-induced activation of DNMT3A. Nature 517: $640-644$.

Guryanova OA, Lieu YK, Garrett-Bakelman FE, Spitzer B, Glass JL, Shank K, Martinez AB, Rivera SA, Durham BH, Rapaport F, et al. 2015. Dnmt3a regulates myeloproliferation and liver-specific expansion of hematopoietic stem and progenitor cells. Leukemia 30: 1133-1142.

Haferlach T, Nagata Y, Grossmann V, Okuno Y, Bacher U, Nagae G, Schnittger S, Sanada M, Kon A, Alpermann T, et al. 2014. Landscape of genetic lesions in 944 patients with myelodysplastic syndromes. Leukemia 28: 241-247.

Handa V, Jeltsch A. 2005. Profound flanking sequence preference of Dnmt3a and Dnmt3b mammalian DNA methyltransferases shape the human epigenome. J Mol Biol 348: 1103-1112.

Hata K, Okano M, Lei H, Li E. 2002. Dnmt3L cooperates with the Dnmt3 family of de novo DNA methyltransferases to establish maternal imprints in mice. Development 129: 1983-1993.

Ho PA, Kutny MA, Alonzo TA, Gerbing RB, Joaquin J, Raimondi SC, Gamis AS, Meshinchi S. 2011. Leukemic mutations in the methylation-associated genes DNMT3A and $\mathrm{IDH} 2$ are rare events in pediatric AML: A report from the Children's Oncology Group. Pediatr Blood Cancer 57: 204-209.

Holz-Schietinger C, Matje DM, Harrison MF, Reich NO. 2011. Oligomerization of DNMT3A controls the mechanism of de novo DNA methylation. J Biol Chem 286: 41479-41488.

Holz-Schietinger C, Matje DM, Reich NO. 2012. Mutations in DNA methyltransferase (DNMT3A) observed in acute 
myeloid leukemia patients disrupt processive methylation. J Biol Chem 287: 30941-30951.

Hou HA, Kuo YY, Liu CY, Chou WC, Lee MC, Chen CY, Lin LI, Tseng MH, Huang CF, Chiang YC, et al. 2012. DNMT3A mutations in acute myeloid leukemia: Stability during disease evolution and clinical implications. Blood 119: $559-568$.

Hu N, Strobl-Mazzulla P, Sauka-Spengler T, Bronner ME. 2012. DNA methyltransferase3A as a molecular switch mediating the neural tube-to-neural crest fate transition. Genes Dev 26: 2380-2385.

Issa JP, Vertino PM, Wu J, Sazawal S, Celano P, Nelkin BD, Hamilton SR, Baylin SB. 1993. Increased cytosine DNAmethyltransferase activity during colon cancer progression. J Natl Cancer Inst 85: 1235-1240.

Ivey A, Hills RK, Simpson MA, Jovanovic JV, Gilkes A, Grech A, Patel Y, Bhudia N, Farah H, Mason J, et al. 2016. Assessment of minimal residual disease in standard-risk AML. N Engl J Med 374: 422-433.

Jaiswal S, Fontanillas P, Flannick J, Manning A, Grauman PV, Mar BG, Lindsley RC, Mermel CH, Burtt N, Chavez A, et al. 2014. Age-related clonal hematopoiesis associated with adverse outcomes. N Engl J Med 371: 2488-2498.

Jankowska AM, Makishima H, Tiu RV, Szpurka H, Huang Y Traina F, Visconte V, Sugimoto Y, Prince C, O'Keefe C, et al. 2011. Mutational spectrum analysis of chronic myelomonocytic leukemia includes genes associated with epigenetic regulation: UTX, EZH2, and DNMT3A. Blood 118: $3932-3941$.

Jeong M, Sun D, Luo M, Huang Y, Challen GA, Rodriguez B, Zhang X, Chavez L, Wang H, Hannah R, et al. 2014. Large conserved domains of low DNA methylation maintained by Dnmt3a. Nat Genet 46: 17-23.

Jeziskova I, Musilova M, Culen M, Foltankova V, Dvorakova D, Mayer J, Racil Z. 2015. Distribution of mutations in DNMT3A gene and the suitability of mutations in R882 codon for MRD monitoring in patients with AML. Int J Hematol 102: 553-557.

Jones PA, Laird PW. 1999. Cancer epigenetics comes of age. Nat Genet 21: 163-167.

Jurkowska RZ, Rajavelu A, Anspach N, Urbanke C, Jankevicius G, Ragozin S, Nellen W, Jeltsch A. 2011. Oligomerization and binding of the Dnmt3a DNA methyltransferase to parallel DNA molecules: Heterochromatic localization and role of Dnmt3L. J Biol Chem 286: 24200-24207.

Kaneda M, Okano M, Hata K, Sado T, Tsujimoto N, Li E, Sasaki H. 2004. Essential role for de novo DNA methyltransferase Dnmt3a in paternal and maternal imprinting. Nature 429: 900-903.

Kiladjian JJ. 2012. The spectrum of JAK2-positive myeloproliferative neoplasms. Hematol Am Soc Hematol Educ Program 2012: 561-566.

Kim SJ, Zhao H, Hardikar S, Singh AK, Goodell MA, Chen T. 2013. A DNMT3A mutation common in AML exhibits dominant-negative effects in murine ES cells. Blood 122: 4086-4089.

Klco JM, Miller CA, Griffith M, Petti A, Spencer DH, Ketkar-Kulkarni S, Wartman LD, Christopher M, Lamprecht TL, Helton NM, et al. 2015. Association between mutation clearance after induction therapy and outcomes in acute myeloid leukemia. JAMA 314: 811-822.
Koike-Yusa H, Li Y, Tan EPP, Velasco-Herrera MDCdC, Yusa K. 2014. Genome-wide recessive genetic screening in mammalian cells with a lentiviral CRISPR-guide RNA library. Nat Biotechnol 32: 267-273.

Koya J, Kataoka K, Sato T, Bando M, Kato Y, Tsuruta-Kishino T, Kobayashi H, Narukawa K, Miyoshi H, Shirahige $\mathrm{K}$, et al. 2016. DNMT3A R882 mutants interact with polycomb proteins to block haematopoietic stem and leukaemic cell differentiation. Nat Commun 7: 10924.

Krause DS, Scadden DT, Preffer FI. 2013. The hematopoietic stem cell niche-Home for friend and foe? Cytometry $B$ Clin Cytom 84: 7-20.

Ley TJ, Ding L, Walter MJ, McLellan MD, Lamprecht T, Larson DE, Kandoth C, Payton JE, Baty J, Welch J, et al. 2010. DNMT3A mutations in acute myeloid leukemia. $N$ Engl J Med 363: 2424-2433.

Liang DCC, Liu HCC, Yang CPP, Jaing THH, Hung IJJ, Yeh TCC, Chen SHH, Hou JYY, Huang YJJ, Shih YSS, et al. 2013. Cooperating gene mutations in childhood acute myeloid leukemia with special reference on mutations of ASXL1, TET2, IDH1, IDH2, and DNMT3A. Blood 121: 2988-2995.

Liao J, Karnik R, Gu H, Ziller MJ, Clement K, Tsankov AM, Akopian V, Gifford CA, Donaghey J, Galonska C, et al. 2015. Targeted disruption of DNMT1, DNMT3A and DNMT3B in human embryonic stem cells. Nat Genet 47: 469-478.

Lin IG, Han L, Taghva A, O’Brien LE, Hsieh CL. 2002. Murine de novo methyltransferase Dnmt3a demonstrates strand asymmetry and site preference in the methylation of DNA in vitro. Mol Cell Biol 22: 704-723.

Marcucci G, Metzeler KH, Schwind S, Becker H, Maharry K, Mrózek K, Radmacher MD, Kohlschmidt J, Nicolet D, Whitman SP, et al. 2012. Age-related prognostic impact of different types of DNMT3A mutations in adults with primary cytogenetically normal acute myeloid leukemia. J Clin Oncol 30: 742-750.

Mayle A, Yang L, Rodriguez B, Zhou T, Chang E, Curry CV, Challen GA, Li W, Wheeler D, Rebel VI, et al. 2015. Dnmt3a loss predisposes murine hematopoietic stem cells to malignant transformation. Blood 125: 629-638.

McKerrell T, Vassiliou GS. 2015. Aging as a driver of leukemogenesis. Sci Transl Med 7: 306fs338.

McKerrell T, Park N, Moreno T, Grove CS, Ponstingl H, Stephens J, Group U, Crawley C, Craig J, Scott MA, et al. 2015. Leukemia-associated somatic mutations drive distinct patterns of age-related clonal hemopoiesis. Cell Rep 10: 1239-1245.

McLean CM, Karemaker ID, van Leeuwen F. 2014. The emerging roles of DOT1L in leukemia and normal development. Leukemia 28: 2131-2138.

Meldi K, Qin T, Buchi F, Droin N, Sotzen J, Micol J-BB, Selimoglu-Buet D, Masala E, Allione B, Gioia D, et al. 2015. Specific molecular signatures predict decitabine response in chronic myelomonocytic leukemia. J Clin Invest 125: 1857-1872.

Meyer SE, Qin T, Muench DE, Masuda K, Venkatasubramanian M, Orr E, Suarez L, Gore SD, Delwel R, Paietta E, et al. 2016. Dnmt3a haploinsufficiency transforms Flt3 $3^{\mathrm{TT}}$ myeloproliferative disease into a rapid, spontaneous, and fully penetrant acute myeloid leukemia. Cancer Discov 6: 501-515. 
L. Brunetti et al.

Mizuno S, Chijiwa T, Okamura T, Akashi K, Fukumaki Y, Niho Y, Sasaki H. 2001. Expression of DNA methyltransferases DNMT1, $3 A$, and $3 B$ in normal hematopoiesis and in acute and chronic myelogenous leukemia. Blood 97: 1172-1179.

Mupo A, Celani L, Dovey O, Cooper JL, Grove C, Rad R, Sportoletti P, Falini B, Bradley A, Vassiliou GS. 2013. A powerful molecular synergy between mutant Nucleophosmin and Flt $3^{\mathrm{ITD}}$ drives acute myeloid leukemia in mice. Leukemia 27: 1917-1920.

Nangalia J, Nice FL, Wedge DC, Godfrey AL, Grinfeld J, Thakker C, Massie CE, Baxter J, Sewell D, Silber Y, et al. 2015. DNMT3A mutations occur early or late in patients with myeloproliferative neoplasms and mutation order influences phenotype. Haematologica 100: e438-442.

Neumann M, Heesch S, Schlee C, Schwartz S, Gökbuget N, Hoelzer D, Konstandin NP, Ksienzyk B, Vosberg S, Graf A, et al. 2013. Whole-exome sequencing in adult ETP-ALL reveals a high rate of DNMT3A mutations. Blood 121: $4749-4752$.

Nimura K, Ishida C, Koriyama H, Hata K, Yamanaka S, Li E, Ura K, Kaneda Y. 2006. Dnmt3a2 targets endogenous Dnmt3L to ES cell chromatin and induces regional DNA methylation. Genes Cells 11: 1225-1237.

Oh BK, Kim H, Park HJ, Shim YH, Choi J, Park C, Park YN. 2007. DNA methyltransferase expression and DNA methylation in human hepatocellular carcinoma and their clinicopathological correlation. Int J Mol Med 20: 65-73.

Okano M, Xie S, Li E. 1998. Cloning and characterization of a family of novel mammalian DNA (cytosine-5) methyltransferases. Nat Genet 19: 219-220.

Okano M, Bell DW, Haber DA, Li E. 1999. DNA methyltransferases Dnmt3a and Dnmt3b are essential for de novo methylation and mammalian development. Cell 99: $247-257$.

Ooi SK, Qiu C, Bernstein E, Li K, Jia D, Yang Z, ErdjumentBromage H, Tempst P, Lin SP, Allis CD, et al. 2007. DNMT3L connects unmethylated lysine 4 of histone H3 to de novo methylation of DNA. Nature 448: 714717.

Otani J, Nankumo T, Arita K, Inamoto S, Ariyoshi M, Shirakawa M. 2009. Structural basis for recognition of H3K4 methylation status by the DNA methyltransferase 3A ATRX-DNMT3-DNMT3L domain. EMBO Rep 10: 1235-1241.

Pang B, Qiao X, Janssen L, Velds A, Groothuis T, Kerkhoven $\mathrm{R}$, Nieuwland $\mathrm{M}$, Ovaa $\mathrm{H}$, Rottenberg $\mathrm{S}$, van Tellingen $\mathrm{O}$, et al. 2013. Drug-induced histone eviction from open chromatin contributes to the chemotherapeutic effects of doxorubicin. Nat Commun 4: 1908.

Papaemmanuil E, Gerstung M, Malcovati L, Tauro S, Gundem G, Van Loo P, Yoon CJ, Ellis P, Wedge DC, Pellagatti A, et al. 2013. Clinical and biological implications of driver mutations in myelodysplastic syndromes. Blood 122: 3616.

Patel JP, Gönen M, Figueroa ME, Fernandez H, Sun Z, Racevskis J, Van Vlierberghe P, Dolgalev I, Thomas S, Aminova O, et al. 2012. Prognostic relevance of integrated genetic profiling in acute myeloid leukemia. $N$ Engl J Med 366: 1079-1089.
Paul TA, Bies J, Small D, Wolff L. 2010. Signatures of polycomb repression and reduced $\mathrm{H} 3 \mathrm{~K} 4$ trimethylation are associated with p15INK4b DNA methylation in AML. Blood 115: 3098-3108.

Pløen GG, Nederby L, Guldberg P, Hansen M, Ebbesen LH, Jensen UB, Hokland P, Aggerholm A. 2014. Persistence of DNMT3A mutations at long-term remission in adult patients with AML. Br J Haematol 167: 478-486.

Qu Y, Lennartsson A, Gaidzik VI, Deneberg S, Karimi M, Bengtzén S, Höglund M, Bullinger L, Döhner K, Lehmann S. 2014. Differential methylation in CN-AML preferentially targets non-CGI regions and is dictated by DNMT3A mutational status and associated with predominant hypomethylation of HOX genes. Epigenetics 9: $1108-1119$.

Rahman MM, Qian ZR, Wang EL, Yoshimoto K, Nakasono M, Sultana R, Yoshida T, Hayashi T, Haba R, Ishida M, et al. 2010. DNA methyltransferases 1, 3a, and 3b overexpression and clinical significance in gastroenteropancreatic neuroendocrine tumors. Hum Pathol 41: 1069-1078.

Renneville A, Boissel N, Nibourel O, Berthon C, Helevaut N, Gardin C, Cayuela JMM, Hayette S, Reman O, Contentin N, et al. 2012. Prognostic significance of DNA methyltransferase $3 \mathrm{~A}$ mutations in cytogenetically normal acute myeloid leukemia: A study by the Acute Leukemia French Association. Leukemia 26: 1247-1254.

Ribeiro AF, Pratcorona M, Erpelinck-Verschueren C, Rockova V, Sanders M, Abbas S, Figueroa ME, Zeilemaker A, Melnick A, Löwenberg B, et al. 2012. Mutant DNMT3A: A marker of poor prognosis in acute myeloid leukemia. Blood 119: 5824-5831.

Robertson KD, Uzvolgyi E, Liang G, Talmadge C, Sumegi J, Gonzales FA, Jones PA. 1999. The human DNA methyltransferases (DNMTs) 1, 3a and 3b: Coordinate mRNA expression in normal tissues and overexpression in tumors. Nucleic Acids Res 27: 2291-2298.

Roller A, Grossmann V, Bacher U, Poetzinger F, Weissmann S, Nadarajah N, Boeck L, Kern W, Haferlach C, Schnittger S, et al. 2013. Landmark analysis of DNMT3A mutations in hematological malignancies. Leukemia 27: 15731578.

Russler-Germain DA, Spencer DH, Young MA, Lamprecht TL, Miller CA, Fulton R, Meyer MR, Erdmann-Gilmore P, Townsend RR, Wilson RK, et al. 2014. The R882H DNMT3A mutation associated with AML dominantly inhibits wild-type DNMT3A by blocking its ability to form active tetramers. Cancer Cell 25: 442-454.

Sakata-Yanagimoto M, Enami T, Yoshida K, Shiraishi Y, Ishii R, Miyake Y, Muto H, Tsuyama N, Sato-Otsubo A, Okuno Y, et al. 2014. Somatic RHOA mutation in angioimmunoblastic T cell lymphoma. Nat Genet 46: $171-175$.

Santini V. 2012. Novel therapeutic strategies: Hypomethylating agents and beyond. Hematology Am Soc Hematol Educ Program 2012: 65-73.

Scourzic L, Couronne L, Pedersen MT, Della Valle V, Diop M, Mylonas E, Calvo J, Mouly E, Lopez CK, Martin N, et al. 2016. DNMT3A ${ }^{\mathrm{R} 882 \mathrm{H}}$ mutant and Tet2 inactivation cooperate in the deregulation of DNA methylation control to induce lymphoid malignancies in mice. Leukemia 30: $1388-1398$. 
Sehgal AR, Gimotty PA, Zhao J, Hsu JMM, Daber R, Morrissette JD, Luger S, Loren AW, Carroll M. 2015. DNMT3A mutational status affects the results of doseescalated induction therapy in acute myelogenous leukemia. Clin Cancer Res 21: 1614-1620.

Shen Y, Zhu YM, Fan X, Shi JY, Wang QR, Yan XJ. 2011. Gene mutation patterns and their prognostic impact in a cohort of 1185 patients with acute myeloid leukemia. Blood 118: $5593-5603$.

Shi J, Wang E, Milazzo JP, Wang Z, Kinney JB, Vakoc CR. 2015. Discovery of cancer drug targets by CRISPR-Cas 9 screening of protein domains. Nat Biotechnol 33: 661667.

Shiba N, Taki T, Park MJJ, Shimada A, Sotomatsu M, Adachi S, Tawa A, Horibe K, Tsuchida M, Hanada R, et al. 2012. DNMT3A mutations are rare in childhood acute myeloid leukaemia, myelodysplastic syndromes and juvenile myelomonocytic leukaemia. Br J Haematol 156: 413-414.

Shlush LI, Zandi S, Mitchell A, Chen WC, Brandwein JM, Gupta V, Kennedy JA, Schimmer AD, Schuh AC, Yee KW, et al. 2014. Identification of pre-leukaemic haematopoietic stem cells in acute leukaemia. Nature 506: $328-$ 333.

Spencer DH, Al-Khalil B, Russler-Germain D, Lamprecht T, Havey N, Fulton RS, O'Laughlin M, Fronick C, Wilson RK, Ley TJ. 2014. Whole-genome bisulfite sequencing of primary AML cells with the DNMT3A R882H mutation identifies regions of focal hypomethylation that are associated with open chromatin. Blood 124: 608-608.

Stegelmann F, Bullinger L, Schlenk RF, Paschka P, Griesshammer M, Blersch C, Kuhn S, Schauer S, Döhner H, Döhner K. 2011. DNMT3A mutations in myeloproliferative neoplasms. Leukemia 25: 1217-1219.

Stieglitz E, Taylor-Weiner AN, Chang TY, Gelston LC, Wang Y-DD, Mazor T, Esquivel E, Yu A, Seepo S, Olsen SR, et al. 2015. The genomic landscape of juvenile myelomonocytic leukemia. Nat Genet 47: 1326-1333.

Suetake I, Mishima Y, Kimura H, Lee YH, Goto Y, Takeshima H, Ikegami T, Tajima S. 2011. Characterization of DNAbinding activity in the N-terminal domain of the DNA methyltransferase Dnmt3a. Biochem J 437: 141-148.

Tatton-Brown K, Seal S, Ruark E, Harmer J, Ramsay E, Del Vecchio Duarte S, Zachariou A, Hanks S, O’Brien E, Aksglaede L, et al. 2014. Mutations in the DNA methyltransferase gene DNMT3A cause an overgrowth syndrome with intellectual disability. Nat Genet 46: 385-388.

Thol F, Damm F, Lüdeking A, Winschel C, Wagner K, Morgan M, Yun H, Göhring G, Schlegelberger B, Hoelzer D, et al. 2011a. Incidence and prognostic influence of DNMT3A mutations in acute myeloid leukemia. J Clin Oncol 29: 2889-2896.

Thol F, Heuser M, Damm F, Klusmann J-HH, Reinhardt K, Reinhardt D. 2011b. DNMT3A mutations are rare in childhood acute myeloid leukemia. Haematologica 96: $1238-1240$.

Thol F, Winschel C, Lüdeking A, Yun H, Friesen I, Damm F, Wagner K, Krauter J, Heuser M, Ganser A. 2011c. Rare occurrence of DNMT3A mutations in myelodysplastic syndromes. Haematologica 96: 1870-1873.

Tie R, Zhang T, Fu H, Wang L, Wang Y, He Y, Wang B, Zhu N, Fu S, Lai X, et al. 2014. Association between DNMT3A mutations and prognosis of adults with de novo acute myeloid leukemia: A systematic review and meta-analysis. PLoS ONE 9: e96653.

Traina F, Visconte V, Elson P, Tabarroki A, Jankowska AM, Hasrouni E, Sugimoto Y, Szpurka H, Makishima H, O'Keefe CL, et al. 2014. Impact of molecular mutations on treatment response to DNMT inhibitors in myelodysplasia and related neoplasms. Leukemia 28: 78-87.

Van Vlierberghe P, Ambesi-Impiombato A, De Keersmaecker K, Hadler M, Paietta E, Tallman MS, Rowe JM, Forne C, Rue M, Ferrando AA. 2013. Prognostic relevance of integrated genetic profiling in adult $\mathrm{T}$-cell acute lymphoblastic leukemia. Blood 122: 74-82.

Walter MJ, Ding L, Shen D, Shao J, Grillot M, McLellan M, Fulton R, Schmidt H, Kalicki-Veizer J, O’Laughlin M, et al. 2011. Recurrent DNMT3A mutations in patients with myelodysplastic syndromes. Leukemia 25: 1153-1158.

Wang J, Qin S, Li F, Li S, Zhang W, Peng J, Zhang Z, Gong Q, Wu J, Shi Y. 2014. Crystal structure of human BS69 Bromo-ZnF-PWWP reveals its role in H3K36me3 nucleosome binding. Cell Res 24: 890-893.

Wolach O, Stone RM. 2015. How I treat mixed-phenotype acute leukemia. Blood 125: 2477-2485.

Wong TN, Ramsingh G, Young AL, Miller CA, Touma W, Welch JS, Lamprecht TL, Shen D, Hundal J, Fulton RS, et al. 2015. Role of TP53 mutations in the origin and evolution of therapy-related acute myeloid leukaemia. $\mathrm{Na}$ ture 518: 552-555.

Wu Z, Huang K, Yu J, Le T, Namihira M, Liu Y, Zhang J, Xue Z, Cheng L, Fan G. 2012. Dnmt3a regulates both proliferation and differentiation of mouse neural stem cells. $J$ Neurosci Res 90: 1883-1891

Xie S, Wang Z, Okano M, Nogami M, Li Y, He WW, Okumura K, Li E. 1999. Cloning, expression and chromosome locations of the human DNMT3 gene family. Gene 236: 87-95.

Xie W, Schultz MD, Lister R, Hou Z, Rajagopal N, Ray P, Whitaker JW, Tian S, Hawkins RD, Leung D, et al. 2013. Epigenomic analysis of multilineage differentiation of human embryonic stem cells. Cell 153: 1134-1148.

Xie M, Lu C, Wang J, McLellan MD, Johnson KJ, Wendl MC, McMichael JF, Schmidt HK, Yellapantula V, Miller CA, et al. 2014. Age-related mutations associated with clonal hematopoietic expansion and malignancies. Nat Med 20: $1472-1478$.

Yan XJJ, Xu J, Gu ZHH, Pan CMM, Lu G, Shen Y, Shi JYY, Zhu YMM, Tang L, Zhang XWW, et al. 2011. Exome sequencing identifies somatic mutations of DNA methyltransferase gene DNMT3A in acute monocytic leukemia. Nat Genet 43: 309-315.

Yang L, Rau R, Goodell MA. 2015. DNMT3A in haematological malignancies. Nat Rev Cancer 15: 152-165.

Yang L, Rodriguez B, Mayle A, Park H, Lin X, Luo M, Jeong M, Curry CV, Kim SB, Ruau D, et al. 2016. DNMT3A loss drives enhancer hypomethylation in FLT3-ITD-associated leukemias. Cancer Cell 29: 922-934.

Yokochi T, Robertson KD. 2002. Preferential methylation of unmethylated DNA by mammalian de novo DNA methyltransferase Dnmt3a. J Biol Chem 277: 11735-11745.

Yoshizato T, Dumitriu B, Hosokawa K, Makishima H, Yoshida K, Townsley D, Sato-Otsubo A, Sato Y, Liu D, Suzuki H, et al. 2015. Somatic mutations and clonal 
L. Brunetti et al.

hematopoiesis in aplastic anemia. N Engl J Med 373: 35 47.

Zhang Y, Rohde C, Tierling S, Jurkowski TP, Bock C, Santacruz D, Ragozin S, Reinhardt R, Groth M, Walter J, et al. 2009. DNA methylation analysis of chromosome 21 gene promoters at single base pair and single allele resolution. PLoS Genet 5: e1000438.

Zhang Y, Jurkowska R, Soeroes S, Rajavelu A, Dhayalan A, Bock I, Rathert P, Brandt O, Reinhardt R, Fischle W, et al. 2010. Chromatin methylation activity of Dnmt3a and Dnmt3a/3L is guided by interaction of the ADD domain with the histone H3 tail. Nucleic Acids Res 38: 4246-4253.

Zhang J, Ding L, Holmfeldt L, Wu G, Heatley SL, PayneTurner D, Easton J, Chen X, Wang J, Rusch M, et al. 2012. The genetic basis of early T-cell precursor acute lymphoblastic leukaemia. Nature 481: 157-163.

Zhang X, Su J, Jeong M, Ko M, Huang Y, Park HJ, Guzman A, Lei Y, Huang YH, Rao A, et al. 2016. DNMT3A and TET2 compete and cooperate to repress lineage-specific transcription factors in hematopoietic stem cells. Nat Genet doi: 10.1038/ng.3610. 


\section{$\&_{\mathrm{CSH}}^{\infty} \&$ Cold Spring Harbor

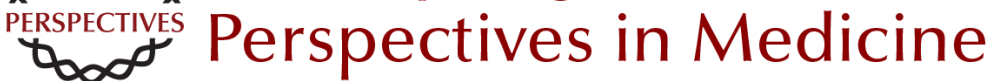

\section{DNMT3A in Leukemia}

Lorenzo Brunetti, Michael C. Gundry and Margaret A. Goodell

Cold Spring Harb Perspect Med 2017; doi: 10.1101/cshperspect.a030320 originally published online December 21, 2016

\section{Subject Collection Chromatin Deregulation in Cancer}

\section{Mixed-Lineage Leukemia Fusions and Chromatin in Leukemia \\ Andrei V. Krivtsov, Takayuki Hoshii and Scott A. Armstrong}

Targeting Cancer Cells with BET Bromodomain Inhibitors

Yali Xu and Christopher R. Vakoc

The Role of Nuclear Receptor-Binding SET Domain Family Histone Lysine Methyltransferases in Cancer

Richard L. Bennett, Alok Swaroop, Catalina Troche, et al.

SETting the Stage for Cancer Development:

SETD2 and the Consequences of Lost Methylation Catherine C. Fahey and lan J. Davis

ATRX and DAXX: Mechanisms and Mutations Michael A. Dyer, Zulekha A. Qadeer, David Valle-Garcia, et al.

DNMT3A in Leukemia

Lorenzo Brunetti, Michael C. Gundry and Margaret A. Goodell

Oncogenic Mechanisms of Histone H3 Mutations Daniel N. Weinberg, C. David Allis and Chao Lu

Nonhistone Lysine Methylation in the Regulation of Cancer Pathways

Scott M. Carlson and Or Gozani
TET2 in Normal and Malignant Hematopoiesis Robert L. Bowman and Ross L. Levine

Long Noncoding RNAs: At the Intersection of Cancer and Chromatin Biology Adam M. Schmitt and Howard Y. Chang

DNA Hypomethylating Drugs in Cancer Therapy Takahiro Sato, Jean-Pierre J. Issa and Patricia Kropf

The Chromodomain Helicase DNA-Binding Chromatin Remodelers: Family Traits that Protect from and Promote Cancer Alea A. Mills

Exploitation of EP300 and CREBBP Lysine

Acetyltransferases by Cancer Narsis Attar and Siavash K. Kurdistani

Histone Lysine Demethylase Inhibitors Ashwini Jambhekar, Jamie N. Anastas and Yang Shi

Cohesin Mutations in Cancer Magali De Koninck and Ana Losada

MLL3/MLL4/COMPASS Family on Epigenetic Regulation of Enhancer Function and Cancer Christie C. Sze and Ali Shilatifard

For additional articles in this collection, see http://perspectivesinmedicine.cshlp.org/cgi/collection/ 